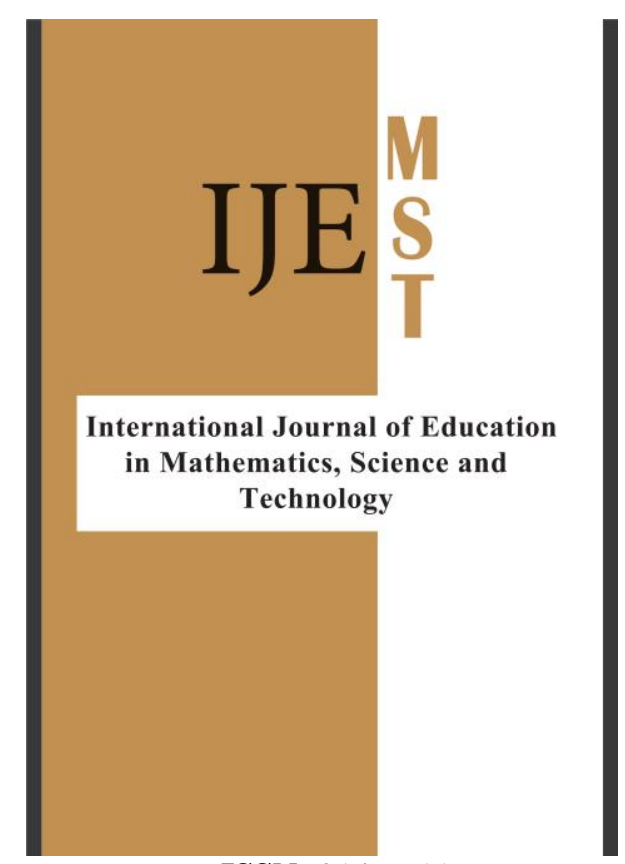

ISSN: $2147-611 \mathrm{X}$
International Journal of Education

in Mathematics, Science and

Technology (IJEMST)

\section{www.ijemst.com}

\section{Engaging Elementary School Pre-service}

Teachers in Modeling a Socioscientific

Issue as a Way to Help Them Appreciate the Social Aspects of Science

\author{
Maria Evagorou', Blanca Puig Mauriz ${ }^{2}$ \\ ${ }^{1}$ University of Nicosia \\ ${ }^{2}$ University of Santiago de Compostela
}

To cite this article:

Evagorou, M. \& Puig Mauriz, B. (2017). Engaging elementary school pre-service teachers in modeling a socioscientific issue as a way to help them appreciate the social aspects of science. International Journal of Education in Mathematics, Science and Technology, 5(2), 113-123. DOI: 10.18404/ijemst.99074

This article may be used for research, teaching, and private study purposes.

Any substantial or systematic reproduction, redistribution, reselling, loan, sub-licensing, systematic supply, or distribution in any form to anyone is expressly forbidden.

Authors alone are responsible for the contents of their articles. The journal owns the copyright of the articles.

The publisher shall not be liable for any loss, actions, claims, proceedings, demand, or costs or damages whatsoever or howsoever caused arising directly or indirectly in connection with or arising out of the use of the research material. 


\title{
Engaging Elementary School Pre-service Teachers in Modeling a Socioscientific Issue as a Way to Help Them Appreciate the Social Aspects of Science
}

\author{
Maria Evagorou, Blanca Puig Mauriz
}

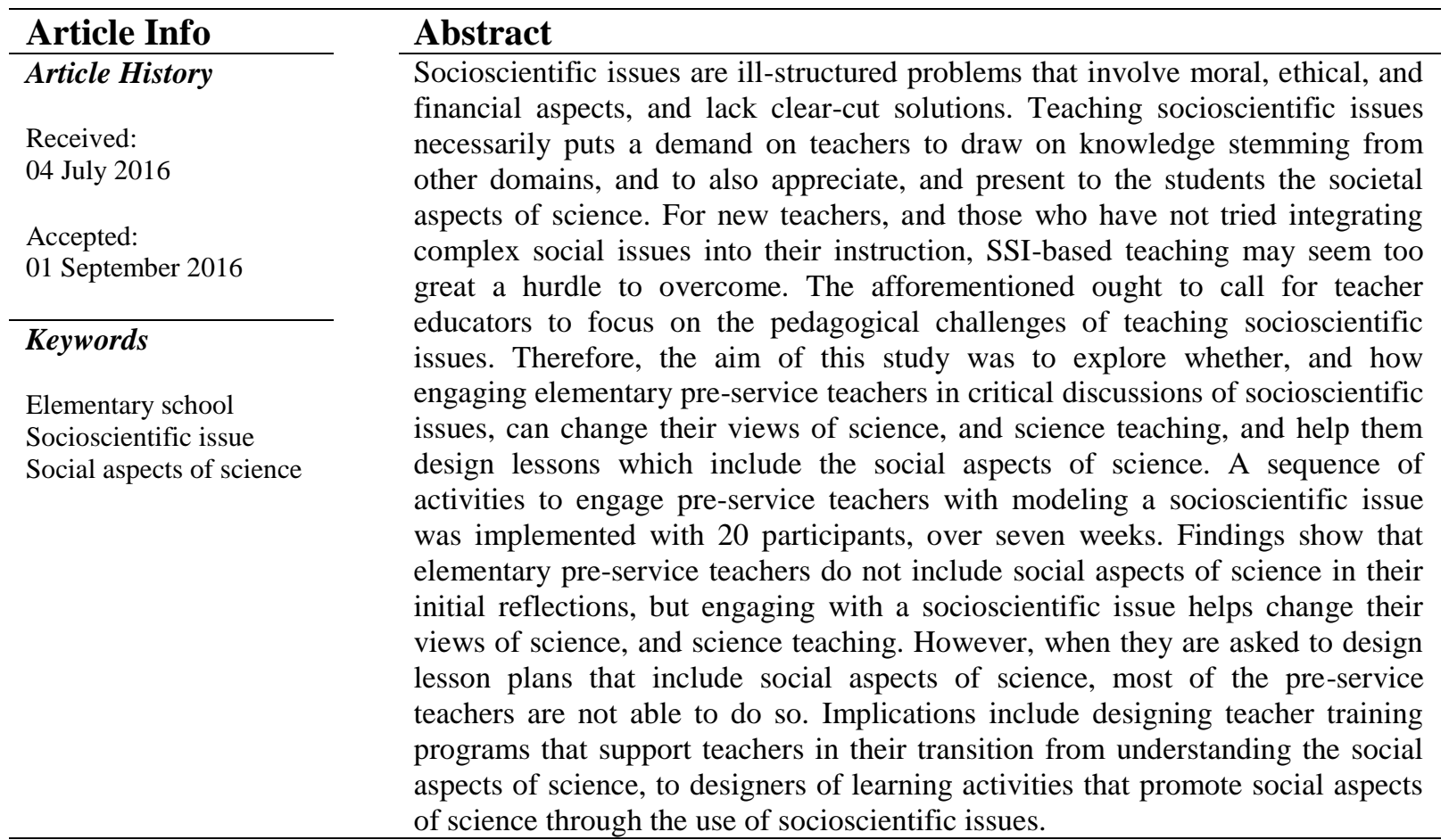

\section{Introduction}

Socioscientific (SSI) issues are ill-structured problems that involve moral, ethical, and financial aspects, and lack clear-cut solutions (Lee \& Grace, 2012; Topcu, Sadler, \& Yilmaz Tuzun, 2010). These are usually topics that emerge from the nexus of science and society (Sadler \& Zeidler, 2004), and are different from the topics presented in the science classroom in terms of the uncertainty that they bring with them. References to socioscientific issues can be found in the science education literature as far as back in the 1980s, and the ability to deal with socioscientific issues has been recognized as an important goal of science education (Zeidler, 2015).

By engaging learners with socioscientific issues, we can potentially help them understand the relevance of science to their lives (Stuckey, Hofstein, Mamlok-Naaman, \& Eilks, 2013), gain insight into what science is, and how people use it, and develop their capacity to be critical consumers of scientific information (Kolstø, 2001; Levinson, 2006). Therefore, socioscientific issues enable learners to recognize that there is a human dimension to the practice of science, and see the connections of science to everyday life (Zeidler, Osborne, Erduran \& Simon, 2003)

More recently, in Europe there has been a move towards Responsible Research and Innovation (RRI), which is "an approach that anticipates and assesses potential implications and societal expectations with regard to research and innovation, with the aim to foster the design of inclusive and sustainable research and innovation" (Commission, 2015). The main emphases of RRI is on science for and with society (Owen, Macnaghten, \& Stilgoe, 2012), and therefore highlights the importance of presenting the societal aspects of science to our learners. With RRI being a new concept in Europe, a lot of researchers link RRI to socioscientific issues and responsible citizenship (Owen et al., 2012). Therefore, the main ideas behind RRI, and socioscientific issues, 
both of which are the emphasis on new curricula in Europe, is that by including socioscientific issues in science learning and teaching we could move science classes towards unwrapping and engaging discussions about the intersections of science and society, and promote scientific practices. Therefore, the inclusion of socioscientific issues in the curriculum offers a means of expanding both the curriculum and the range of instructional practices commonly experienced in the school science classroom.

Studies in socioscientific issues have mostly focused on learners' argumentation and decision making (e.g. Evagorou \& Osborne, 2013; Evagorou, Jimenez-Aleixandre, \& Osborne, 2012; Jimenez-Aleixandre, 2002; Ratcliffe, 1997), on informal reasoning (e.g. Sadler \& Zeidler, 2004; Topcu et al., 2010), conceptual understanding (e.g. Sadler \& Fowler, 2006; Zohar \& Nemet, 2001), and engagement with science (e.g. Albe, 2007). Even though there has been an increasing focus on supplementing science teaching with a focus on socioscientific issues, in such contexts, teachers find it challenging to guide the learning and assess the performance of students in terms of whether they use scientific evidence or whether the claimed evidence is in fact true (Evagorou, 2011). Consequently, teaching socioscientific issues necessarily puts a demand on teachers to draw on knowledge stemming from other domains, and to also appreciate, and present to the students the societal aspects of science (L. Simonneaux \& Simonneaux, 2008a). For new teachers, and those who have not tried integrating complex social issues into their instruction, SSI-based teaching may seem too great a hurdle to overcome (Levinson, 2006), especially when social aspects of science are not part of their teaching philosophies. The afforementioned ought to call for teacher educators to focus on the pedagogical challenges of teaching socioscientific issues (Forbes \& Davis, 2007), but so far there is limited research on socioscientific issues teaching as part of either in-service, or pre-service teacher education (Evagorou et al., 2014).

Even though studies with in-service, and pre-service teachers in the area of SSI are limited, our previous work has shown that teachers face similar difficulties in dealing with SSI as their students (Evagorou, 2015). For example, they do not make the connection between science and SSI since they find it difficult to coordinate between scientific data and the social aspects of the problem which bring uncertainty into the discussions. Furthermore, our previous study with elementary pre-service teachers (PSTs) has shown that they have limited science content knowledge - which limits their ability to understand and evaluate the claims offered by the students; have a limited understanding of what science is and the social aspects of doing science, and finally, have negative emotions towards science, and teaching science (Evagorou et al., 2014).

Starting from the aforementioned gap in the literature, the aim of this study was to explore whether, and how engaging elementary pre-service teachers in critical discussions of socioscientific issues, can change their views of science, and science teaching. The motivation to design and implement such a study comes: (a) from limited research and curriculum development in the area of SSI and teacher education, especially with elementary preservice teachers, (b) the importance of supporting future teachers in developing an understanding of the social aspects of science and SSI, and potentially incorporating them in their teaching, and (c) the emphasis on the inclusion of RRI aspects in science curricula in Europe. Therefore, what we aim to do in this study is to explore whether engaging elementary pre-service teachers in the modeling of a socioscientific issue can change their understanding of what science is, and can provide them with a more holistic understanding of science, and teaching science in their classes. More specifically, the research questions guiding this study are:

1. How do elementary pre-service teachers ideas about what science is change after engaging with a socioscientific issue?

2. What are elementary pre-service teachers ideas about teaching science after engaging with a socioscientific issue?

3. Do elementary pre-service teachers design activities to teach social aspects of science?

\section{Socioscientific Issues}

Socioscientific issues are different from the problems usually presented in science classrooms, since they are illstructured and involve moral and ethical aspects. In our work we define socioscientific issues as those issues on which our society, or science are clearly divided and significant groups advocate conflicting explanations or solutions based on alternative values. Hence, one can conclude that socioscientific problems are ill-defined and value-laden, invoking aesthetic, ecological, economic, moral, educational, cultural, religious and recreational values that are constrained by missing knowledge (Chiapetta, Koballa \& Collette, 1998).

Therefore, when we teach SSI we aim: "to improve knowledge understanding, to contribute to citizenship education, to help students to make informed decisions, to empower them to participate in debates, to help them to be able to deal with complexity, and to understand better the nature of science" (L. Simonneaux \& 
Simonneaux, 2008b) p. 181). According to Zeidler, Sadler, Simmons and Howes (2005), SSI education "is equated with the consideration of ethical issues and construction of moral judgements about scientific topics via social interaction and discourse" (p.360). Engaging students in SSI activities can potentially promote decision making about social issues with moral implications, focusing at the same time on character formation. In that way, with SSI, students are exposed to moral problems with scientific, social and moral viewpoints, which might conflict with their personal views, forcing them to focus on the use and interpretation of data and the analysis of conflicting evidence to engage in discussions of viewpoints that might be different from their original ones.

Research on SSI has focused primarily on students argumentation and decision making, and their informal reasoning when engaging with SSI. A study by Zeidler, Walker, Ackett and Simmons (2002) showed that students with naive and relativistics conceptions of science will dismiss any data and will focus on their initial ideas. Similarly, in a study by Ratcliffe (1997) secondary school students were asked to judge whether a certain claim could be regarded as proven. Some students accepted some information without evaluation, others pointed to insufficient evidence, or to the possible role of the scientists' integrity or beliefs. In a similar study Evagorou, Jimeneiz-Aleixandre and Osborne (2012) explored students' argumentation and decision making within a socioscientific issue and found that secondary school students identify with actors of the SSI and tend to make decisions based on how they identify with the issue, ignoring the evidence that does not support their views. These results suggest that students are not prepared to evaluate knowledge claims, or to support their answers based on evidence, but other aspects of the SSI (personal, moral, ethical) are more important during the decision making.

Even though studies with in-service and pre-service teachers in the area of SSI are limited, most of the available studies show that students and teachers face similar difficulties when dealing with SSI. For example, Bell and Lederman (2003) studied university professors' reasoning and found out that the primary influence guiding their decisions were personal values. Topcu and collegues (2010) explored the influence of the context on pre-service teachers informal reasoning. Their findings show that informal reasoning in SSI is context dependent, especially in terms of the extent to which those engaged in reasoning understand the content. This finding is linked to Sadler and Fowler's (2006) claim that "there is a significant link between informal reasoning in the context of SSI and content understanding” (p. 2490).

Finally, Sadler, Amirshokoohi, Kazempour, and Allspaw (2006) explored the profiles of teachers when it comes to applying ethics in the science classroom, as they believe that teachers beliefs can drive their teaching practices. Based on their analyses, five profiles of teachers were identified, from teachers who view SSI as central to science education and implement them in their classrooms, to teachers who can understand the link between ethics and science in SSI but were ambivalent towards implementing SSI in their classes. However, research on how teachers profiles actually influence their teaching practices is still limited, and as Zeidler (2015) suggests, we still need to explore how pre-service and in-service teachers best develop their identities towards SSI, and how these identities can inform their teaching and consequently, students' learning.

\section{Socioscientific Issues and Teacher Education}

Crawford (2007), in a recent study with teachers, has concluded that:

A prospective teacher's personal view of teaching science $[\ldots]$ is a strong predictor of a prospective teacher's actual practice of teaching science (p.637).

Hence an important aspect of preparing teachers to teach SSI be to provide them with experiences that will change their view of teaching science into one with includes the social and ethical perspectives of science as well. If we want to do this, we need to engage pre-service teachers themselves in SSI as learners. For our study, the sequence of activities that was designed for the pre-service teachers was based on the notion of Pedagogical Content Knowledge (Park, Jang, Chen, \& Jung, 2010), which recognizes that knowledge of the pedagogy is as important as content knowledge for teachers. Therefore the pre-service teachers need to experience the content and the practices as learners themselves and then transform it into teaching practices.

According to Friedrichsen, Sadler, Sadler, Graham and Brown (2016) there is limited research on the implementation of SSI-based research despite of the calls on the importance on SSI. The authors state that this might be due to the fact that there is a lack of SSI materials to be used, and secondly there is limited support to 
teachers trying to enact SSI. Furthermore, as we have identified in one of our projects (Evagorou et al., 2014), there is limited pre-service teacher training on SSI, especially in European countries.

The few studies exploring the teaching practices of in-service and pre-service teachers show that teachers are uncertain when it comes to implementing SSI in their classes. In one of our studies in which an elementary preservice teacher implemented an SSI curriculum (Evagorou, 2011), the teacher indicated at the end of the implementation that he felt uncertain about using SSI with his class because he did not know the correct answer to the questions that the students were asking about the SSI, and he could not deal with the multiple solutions, and the ethical implications. Similarly, in a study in which we aimed to explore how elementary pre-service teachers understand SSI, and then implement them in their designs (lesson plans) and teaching (Evagorou, 2015; Evagorou et al., 2014), we found that elementary PSTs: (a) Find it difficult to understand what SSI is before engaging themselves as learners with SSI, (b) They feel uncomfortable designing ssi argumentation lesson plans because of: (1) the complexity of the SSI issues, both as a content and as a context, and (2) because they are unsure of how to plan and scaffold discursive activities; (c) They are uncertain about the 'correct' answer in the topic they are teaching, especially due to their limited content knowledge; (d) They find it difficult to evaluate students' SSI arguments during the discussions in the classroom, and provide feedback.

Sadler (2011) suggested a model on the essentials of teaching SSI in which design elements and learner experiences are importnant, but also important attributes are the teacher and the classroom environment. Based on the model, the essential teacher attributes are: (a) they are familiar with issues being considered which involves knolwedge about science content related to the issue, and awareness of the social considerations associated with the issue; (b) being honest about knowledge limitations; (c) willing to deal with uncertainties in the classroom; and (d) willing to position themselves as knowledge contributors rather than the sole authority.

Based on the afforementioned model, as science educators we need to prepare pre-service teachers to change their views of science, and their teaching practices to adjust to their view, and therefore in this study we explore elementary PSTs views of social considerations of science.

\section{Methodology}

This is an exploratory case study of a university classroom (Merriam, 1988) aiming to explore how elementary pre-service teachers' views about science, and the importance of teaching science can change when they engage in the modeling of a socioscientific issue.

\section{Context of the Study and Participants}

The participants of the study were 20 pre-service teachers, studying to become elementary school teachers at a university in Europe. All the participants (18 female and 2 male) were in their 3rd year of studies of a 4 -year Bachelor degree in Education. All participants were enrolled in the Research Methods in Science Education course, that is taught in the $3^{\text {rd }}$ year of their study, and has a duration of 13 weeks. The purpose of the course is to familiarize the pre-service teachers with teaching practices in science education, train them on how to organize science lesson plans for the local curriculum, and prepare them to engage the students with scientific practices. None of the elementary pre-service teachers had a background in science, but all of them attended two compulsory content related courses during their studies, one in Biology and one in Physics.

\section{Activity Sequence}

For the purpose of this study, a sequence of activities was designed in order to promote the exploration of a socioscientific issue through modeling the issue itself. Our design follows is similar to the one used by Friedrichsen et al. (2016) in which they designed an SSI curriculum using the following ideas: presentation of an issue that is compelling for the students, students work with the phenomenon through engaging in scientific practices (namely modeling and explanation in our study), and making use of technology - therefore content and practices develop together, and finally the evaluation on the explanations provided by the students. When the implementation of the activities begun, the pre-service teachers did not have any previous experience with argumentation, modeling or socioscientific issues. 
The socioscientific issue that we chose for this study is that of the declining population of the bees. Specifically, the population of the bees around the world is declining, and in the long-term this can affect the crops, biodiversity, and the production of food. In our work we define as socioscientific issues those on which society, or science are clearly divided and significant groups advocate conflicting explanations or solutions based on alternative values. Hence, one can conclude that controversial issues are ill-defined and value-laden, and are constrained by missing knowledge. The controversy of this specific issue is related to the causes of the declining population of the bees, the consequences and then, in the possible solutions.

In order to engage the pre-service teachers with this socioscientific issue, we decided to design a sequence of activities during which they would explore the issue through engaging with modeling and explanation in their groups. During each week the pre-service teachers worked in groups of 3 or 4 , for 3 hours each week.

Week 1: During the first week of the instruction the pre-service teachers engaged in an inquiry-based activity in which they had to explore the characteristics (smell, test, density, colour) of different types of honey, and then identify them. Specifically, five bottles with different types of honey were provided to each group of PSTs, and they had to study them in terms of their different characteristics, and then based on an identification key they had to recognize the type of honey, linking it to the characteristics of the pollen that it came from. The purpose of this activity was to engage the PSTs in the process of understanding where the honey comes from, and what is the role of the bees in this process.

Week 2: During the second week the PSTs were provided with some information on honeybees, and how their communities are organized. The purpose was to understand how the community of honeybees works inside a hive, and how the bees interact with the environment. The PSTs could also use the computers in the classroom to collect any other information from the Internet. The final outcome of this activity was a two-dimensional model of the hive showing the relationships in the hive (queen, drones, workers), and how they interact with the outside environment.

Week 3 \& 4: During the $3^{\text {rd }}$ and $4^{\text {th }}$ weeks, the PSTs constructed three-dimensional models of bee hives an their environments. During the model construction process each group received feedback from the instructor and other groups as to how effective their model was in presenting the processes that take place both within, and outside the bee-hive. At the end of week 5 all groups presented and explain their models.

Week 5 \& 6: During the $5^{\text {th }}$ and $6^{\text {th }}$ week the PSTs were presented to the problem: "The population of the bees worldwide is declining. Should we care, and why?" Initially they were asked to give their answers as groups, using their knowledge from constructing their models to explain their answers. Then, they were provided with different scenarios that have to do with causes of the declining population of the bees (e.g. varroa mite, people destroying natural habitats, chemical spraying of crops), and they were asked to use their models to explain the problem, to show the changes that are taking place over time in their models, both short-term and long-term. For each of the scenario they had to prepare a short video-clip showing the consequences, using their model, and argue about possible solutions.

Week 7: During this week the students reflected on the activities, and discussed why the bees issue is an SSI. Furthermore, they were asked to choose a topic that they wanted to teach to elementary school students, and design lesson plan. This was their final project.

\section{Data Collection}

During the semester the following data were collected from all the participants of the course:

Pre and post-reflections exploring PSTs ideas on what science is and how it should be taught: Specifically, the PSTs were asked to explain in their reflective diaries what science is for them, and how it should be taught, both at the beginning of the semester, and the end of the semester and provide examples. At the post-reflection they were also asked to describe or draw how their class will be organized when they teach science. Guiding questions were provided for the reflective diaries, but the questions were open-ended and the PSTs could reflect freely on any aspect of the lessons.

Pre and post-tests exploring PSTs' understanding of honeybees communities and their importance: The PST's were asked where honey comes from, and how the bee community is organized. They were also asked to explain whether they agree or not with Einstein's claim that the world will come to an end when bees are 
extinct. Videos from each group explaining and arguing about the changes in models based on the scenarios, and observations from the implementation of the activity sequence, PSTs assignment: in which they had to design a lesson plan to teach science to elementary school students. The students were free to chose either a scientific, or socioscientific issue. However, we analysed all assignments in order to identify whether the PSTs' profile are in accordance with their actual designs.

For the purposes of this paper only PSTs' reflections and assignments are analysed, as presented below. The videos and observations from the interactions are analysed in another paper that explores how modeling contributes to the exploration of socioscientific issues.

\section{Research Question}

R.Q. 1: How do elementary pre-service teachers ideas about what science change after engaging with a socioscientific issue?

R.Q. 2: What are elementary pre-service teachers ideas about teaching science after engaging with a socioscientific issue?

R.Q. 3: Whether, and how elementary pre-service teachers design activities to teach social aspects of science?
Data

- $\quad$ Pre and post reflections

- $\quad$ Pre and post reflections

- Assignments - lesson plans

\section{Data Analysis}

All data were open-coded, looking for themes that related to the three research questions. Specifically, the reflections were analyzed looking for themes on how PSTs view science and science teaching, and how they imagine their future class. From the open-coding of the responses on both the pre- and post-reflections the profiles presented in Table 1 were recorded. These profiles are based on whether the PSTs made reference to the content of science, the skills of science, and the social aspects of science.

Table 1. Description of coding categories for PSTs profiles

\begin{tabular}{|c|c|}
\hline Name & Description \\
\hline Profile 1: Science as Content & $\begin{array}{l}\text { Science is about: } \\
\text { - Understanding the environment } \\
\text { - Providing theories } \\
\text { - Medicine/technology } \\
\text { - Discoveries/experiment }\end{array}$ \\
\hline Profile 2: Science as Skills & $\begin{array}{cl}\text { Science is about: } \\
\text { • } & \text { Explanations } \\
\bullet & \text { Observation } \\
\text { • } & \text { Inquiry }\end{array}$ \\
\hline $\begin{array}{l}\text { Profile 3: Science as Skills and } \\
\text { Content }\end{array}$ & Includes the descriptions in profiles $1 \& 2$ \\
\hline $\begin{array}{l}\text { Profile 4: Social Aspects of } \\
\text { Science and Skills }\end{array}$ & $\begin{array}{l}\text { Science is about: } \\
-\quad \text { working in groups to solve problems } \\
-\quad \text { learning skills that can help in society } \\
-\quad \text { becoming responsable citizens } \\
-\quad \text { connecting everyday life to scientific discoveries } \\
-\quad \text { making informed decisions } \\
-\quad \text { appreciating others' opinions }\end{array}$ \\
\hline $\begin{array}{l}\text { Profile 5: Social Aspects of } \\
\text { Science, Skills and Content }\end{array}$ & $\begin{array}{l}\text { Includes the decription in Profile } 4 \text {, plus the importance of learning } \\
\text { the content of science. }\end{array}$ \\
\hline
\end{tabular}

The profile of each individual student was also created based on their reflections. PSTs reflections on teaching science were also open-coded using the categories in Table 1. Then, the assignments (the goals of the lesson plans) were analyzed in order to identify: (a) which assignments were designed to promote socioscientific issues, (b) to identify whether they included goals to promote the social aspects of science, and (c) to identify whether they included goals for skills. 


\section{Findings}

The analysis described in this section explored how elementary pre-service teachers' views of what science is changes after the implementation of a sequence of activities focusing on a socioscientific issue. Furthermore, our analysis explored elementary pre-service teachers' views of science teaching after engaging with a socioscientific issue, and whether their lesson were in line with how they viewed the teaching of science.

R.Q.1 PSTs ideas about science before and after engaging with a socioscientific issue.

An analysis of PSTs' views of science before and after the instruction is presented in Table 2 below.

As shown in Table 2, the participants of the study did not refer to the social aspects of science before engaging with the socioscientific issue. On the contrary, they talked about science either as content, as skills, or as the combination of content and skills. The following is a representative quote for students that believed that science is about content and skills (Profile 3):

Table 2. PSTs views of science before and after the instruction

\begin{tabular}{llll}
\hline Profile & Description & $\begin{array}{c}\text { Before } \\
\text { N=20 }\end{array}$ & $\begin{array}{c}\text { After } \\
\text { N=20 }\end{array}$ \\
\hline Profile 1 & Science as Content & 6 & 1 \\
\hline Profile 2 & Science as Skills & 6 & 5 \\
\hline Profile 3 & Science as Skills and Content & 8 & 3 \\
\hline Profile 4 & Social Aspects of Science and Skills & 0 & 7 \\
\hline Profile 5 & Social Aspects of Science, Skills and Content & 0 & 4 \\
\hline
\end{tabular}

Science has to do with understanding the environment, learning about theories, it has to do with medicine and discoveries. It also has to do with experimenting, analyzing data, observing and explaining (PST 1 pre-reflection).

After engaging with the socioscientific issues, more than half of the participants offer a view of science that refers to the social aspects of science as well.

Science is not only about the theories. It is also about the scientific practices. By engaging students in the modeling of a socioscientific issue we allow them to explore the topic and discover on their own the characteristics of science. In this way the students gain autonomy and develop critical thinking. Through science the students can make decisions based on evidence - a skill that will help them as future citizens (PST 4, post-reflection)

The pre-service teachers who refer to the social aspects of science in their post reflections, talk about science as helping them learn skills that are useful in society, helping them become responsible citizens, connect everyday life to scientific discoveries, and make informed decisions. As one of the pre-service teachers explains:

Engaging with science can help us on a personal and social level. On a personal level we can learn to collaborate, a skill that is useful in our everyday lives, and also we can learn how to solve a problem and find evidence to support what we are saying. Science provides the learner with the necessary skills to use in society, as for example collecting and evaluating evidence, and using evidence to support ideas (PST 1 - post- reflection).

Three of the pre-service teachers refer to the specific socioscientific issue that was used for the instruction in their reflection to link it with social aspects of science. Specifically, these pre-service teachers refer to to community of bees as a model that can demonstrate how we should be collaborating as scientists and as societies. Specifically,

Science can help form a person's character and help them have a critical evaluation towards questions by looking into data and evaluating data. By engaging in socioscientific issues in science, we can use our knowledge from science in other topics as well. For example, during the bees lesson we learned how the bees are organized which gave us an example on how society can function, and how important each member of the society is in achieving something collaboratively. Through this example, through science, we can understand what it means to be a responsible member of the society (PST 6 - postreflection). 
R.Q.2. What are pre-service teachers' ideas about teaching science after engaging with a socioscientific issue? For the purposes of the second research question of this study, elementary pre-service teachers' reflections about teaching science were analyzed. The analysis is presented in Table 3 below.

Table 3. PSTs view of teaching science

\begin{tabular}{lll}
\hline Profile & Description & $\mathrm{N}=20$ \\
\hline Profile 1 & Science as Content & 0 \\
\hline Profile 2 & Science as Skills & 6 \\
\hline Profile 3 & Science as Skills and Content & 4 \\
\hline Profile 4 & Social Aspects of Science and Skills & 6 \\
\hline Profile 5 & Social Aspects of Science, Skills and Content & 4 \\
\hline
\end{tabular}

As evident in Table 3, none of the students refers to teaching science only as content after engaging with a socioscientific issue. Half of the PSTs still refer to the teaching of science as placing emphasis on the skills and content with no reference to the social aspects of science. A representative example from focusing on teaching science as skills is PST 3:

I will use group work in my class to teach science. The students will work collaboratively on a problem that will be presented to them to develop their communication skills (PST 3 - post reflection).

The PSTs who referred to the social aspects of teaching science, used references to the socioscientific issue that was taught in the class. For example:

I imagine using socioscientific issues as part of my teaching in science as a way to introduce my students to the social aspects of science. Through the engagement with the socioscientific issue the students will be excited and engaged with the topic. The students should experiment themselves, use materials, solve problems that make sense to them. I will never give them the answers, but will allow them to explore the issues, and support them in collecting and evaluating the evidence themselves. As we did with the bees - we were guided through constructing our model to find more information about the bee ecosystem to be able to model it, and then more information about the threats to the bees to be able to understand how to propose a solution (PST 14 - post reflection).

What was also evident in all reflections of PSTs who were coded as appreciating the social aspects of science (Profiles 4 and 5), is that they all made reference to teaching science in a way that will make their students happy. For example:

By working on their own and exploring issues that they find interesting and are part of their lives they will be happy and active during the lesson. It is important for the students to love science and understand what science has to offer in their lives (PST 4 - post-reflection).

Finally, in their post-reflections about teaching science some of the participants chose to either draw, or describe their class and how it will be organized. All PSTs who made a reference to the social aspects of science described or drew a class that was similar to our class during the implementation - a lab in which the students worked in groups, had access to materials and computers, and were free to move in the classroom, with the teacher supporting them during their collaboration.

R.Q.3 Whether, and how elementary pre-service teachers design activities to teach social aspects of science? In order to explore whether PSTs' designs are consistent with their views about science and teaching science, we asked the elementary pre-service teachers to prepare lesson plans to teach a unit from the local curriculum. The participants were free to choose either a scientific, or a socioscientific issue. Out of the 20 participants, only five chose a socioscientific issue for their lesson plans. Table 4 presents the profiles for each one of the participants of the study, with the last columns focusing on the analysis of the lesson plans.

Based on Table 4, only six of lesson plans referred in their goals to the social aspects of science (e.g. make the connection between science and their lives, become responsible citizens, appreciate the moral and ethical aspects of the issue). Five of the lesson plans that referred to the social aspects of science were designed to teach a socioscientific issue, whilst one of the lessons was designed to teach a scientific issue. Furthermore, the analysis of the goals of the lesson plans revealed that all elementary pre-service teachers included goals to promote skills of science (e.g. modeling, collaboration, explanation, decision-making). 
Finally, exploring the PSTs' profiles (Table 4) reveals that PSTs' with more traditional initial views of science, as for example participant 3 (P3) and participant 11 (P11) did not change their views of science after engaging with a socioscientific issue, whilst participants who were categorized under Profile 3 (science as content and skills) moved to a view of science, and science teaching that includes references to social aspects of science (e.g. P11, P13). Additionally, even though half of the participants hold views of teaching science that promote the social aspects of science, they do not seem to design their lesson plans in a way which promotes engaging in the social aspects of science, as only 5 of those participants make reference to the social aspects of science in their designs.

Table 4. Participants' profiles

\begin{tabular}{|c|c|c|c|c|c|c|}
\hline \multirow{2}{*}{$\begin{array}{l}\text { Participa } \\
\text { nts }\end{array}$} & \multirow{2}{*}{$\begin{array}{l}\text { View of Science } \\
\text { before }\end{array}$} & \multirow{2}{*}{$\begin{array}{l}\text { View of Science } \\
\text { after }\end{array}$} & \multirow{2}{*}{$\begin{array}{l}\text { View about teaching } \\
\text { science }\end{array}$} & \multicolumn{3}{|c|}{ Lesson Plans } \\
\hline & & & & Type of Issue & $\begin{array}{l}\text { Reference } \\
\text { to Social } \\
\text { Aspects }\end{array}$ & $\begin{array}{l}\text { Reference } \\
\text { to Skills }\end{array}$ \\
\hline $\mathrm{P} 1$ & Profile 3 & Profile 4 & Profile 4 & Scientific & No & Yes \\
\hline $\mathrm{P} 2$ & Profile 1 & Profile 2 & Profile 2 & Scientific & No & Yes \\
\hline $\mathrm{P} 3$ & Profile 2 & Profile 2 & Profile 2 & Scientific & No & Yes \\
\hline $\mathrm{P} 4$ & Profile 2 & Profile 4 & Profile 4 & SSI & Yes & Yes \\
\hline P5 & Profile 2 & Profile 2 & Profile 2 & Scientific & No & Yes \\
\hline P6 & Profile 2 & Profile 3 & Profile 3 & Scientific & No & Yes \\
\hline $\mathrm{P} 7$ & Profile 2 & Profile 3 & Profile 3 & Scientific & No & Yes \\
\hline P8 & Profile 2 & Profile 3 & Profile 3 & Scientific & No & Yes \\
\hline P9 & Profile 3 & Profile 4 & Profile 3 & Scientific & No & Yes \\
\hline $\mathrm{P} 10$ & Profile 3 & Profile 5 & Profile 4 & Scientific & No & Yes \\
\hline P11 & Profile 1 & Profile 1 & Profile 2 & Scientific & No & Yes \\
\hline P12 & Profile 3 & Profile 5 & Profile 5 & SSI & Yes & Yes \\
\hline P13 & Profile 3 & Profile 5 & Profile 5 & SSI & Yes & Yes \\
\hline P14 & Profile 3 & Profile 4 & Profile 4 & Scientific & No & Yes \\
\hline P15 & Profile 1 & Profile 4 & Profile 4 & SSI & Yes & Yes \\
\hline P16 & Profile 3 & Profile 5 & Profile 5 & SSI & Yes & Yes \\
\hline P17 & Profile 1 & Profile 2 & Profile 2 & Scientific & No & Yes \\
\hline P18 & Profile 3 & Profile 5 & Profile 5 & Scientific & Yes & Yes \\
\hline P19 & Profile 1 & Profile 2 & Profile 2 & Scientific & No & Yes \\
\hline $\mathrm{P} 20$ & Profile 3 & Profile 4 & Profile 4 & Scientific & No & Yes \\
\hline
\end{tabular}

\section{Conclusions and Discussion}

The purpose of this study was to explore whether engaging elementary pre-service teachers in the modeling of a socioscientific issue can change their understanding of what science is, and how it should be taught, and if the possible changes in their views are reflected in their lesson plans. Our first finding is that elementary preservice teachers, before engaging with a socioscientific issue, do not understand the social aspects of science, and they only focus on the content and skills of science. This finding is consistent with findings from previous studies which show that pre-service teachers, and especially elementary pre-service teachers hold traditional views of science who are based on their experiences as learners of science themselves (e.g. Crawford, 2007; Forbes \& Davis, 2007). Our second findings is that after engaging with the modeling of a socioscientific issue, more than half of the pre-service elementary teachers (11/20) change their views to include social aspects of science (e.g. science as promoting responsible citizenship, understanding of the moral and ethical aspects of science). We hypothesize that the PSTs views of science changed as a result of engaging with the modeling of a socioscientific issue during the implementation of our teaching sequence, especially given that they had no other interaction with a similar topic during the seven weeks of the implementation. Our hypothesis is also supported by the content of the PSTs' reflections in which they make specific reference to examples from the teaching sequence. This finding is important, as it shows that PSTs can change their views of science through engaging with a socioscientific issue, in a relatively short period of time. However, it is also important to note that 9/20 PSTs did not change their views of science, and this is something that needs to be further explored to identify why some PSTs are more resistant than others, and how to further support them. 
A third finding of this study reveals that elementary pre-service teachers' views of science are consistent with their views of teaching science. Specifically, almost all PSTs who view science as having social aspects also refer to the importance of promoting the social aspects of science through their teaching (e.g. responsible citizenship, making informed decisions, understanding the moral and ethical aspects of science). Furthermore, these PSTs model their views of teaching science on how the socioscientific issue was taught during the application of the teaching sequence of the socioscientific issue (e.g. they provide examples of teaching practices that resemble their experience as learners in our teaching sequence). This is consistent with previous studies based on which teachers model their own practices on experiences they had as learners themselves (e.g. Crawford, 2007; Forbes \& Davis, 2007). We consider this as an important contribution of our study, given that previous studies did not explicitly explore the teaching practices linked to the teaching of the social aspects of science through the use of socioscientific issues.

Finally, a fourth finding of this study is that, PSTs' views of science and teaching science might be consistent, but there is no consistency between their views of teaching science and their designs in their lesson plans for those PSTs that present an understanding of the social aspects of science. More specifically, even though some PSTs held a view of science, and teaching science with an emphasis on the social aspects of science, when it came to designing lesson plans they did not incorporate these views in their lessons. We hypothesize that this might indicate a naïve understanding of the social aspects of science, and that PSTs need more time, and practice, to transition from learners of science, to designers of activities.

Implications from this study are associated with finding ways to support teachers in understanding the importance of social aspects of science, and teaching the social aspects of science. Another important implication is associated with exploring pre-service teachers' difficulties in designing learning activities to promote the social aspect of science through the use of socioscientific issues, and most importantly how the preservice teachers transition from learners to teachers of the social aspects of science.

\section{References}

Albe, V. (2007). When Scientific Knowledge, Daily Life Experience, Epistemological and Social Considerations Intersect: Students' Argumentation in Group Discussions on a Socio-scientific Issue. Research in Science Education, 38(1), 67-90. http://doi.org/10.1007/s11165-007-9040-2

Commission, E. (2015). Science Education for Responsible Citizenship (pp. 1-88). European Commision.

Crawford, B. A. (2007). Learning to teach science as inquiry in the rough and tumble of practice. Journal of Research in Science Teaching, 44(4), 613-642. http://doi.org/10.1002/tea.20157

Evagorou, M. (2011). Discussing a Socioscientific Issue in a Primary School Classroom: The Case of Using a Technology-Supported Environment in Formal and Nonformal Settings. In Socio-scientific Issues in the Classroom (Vol. 39, pp. 133-159). Dordrecht: Springer Netherlands. http://doi.org/10.1007/978-94007-1159-4_8

Evagorou, M. (2015). Transferring knowledge about socio-scientific argumentation to teaching practice. Presented at the Symposium presentation at the European Science Education Research Association Meeting.

Evagorou, M., \& Osborne, J. (2013). Exploring young students' collaborative argumentation within a socioscientific issue. Journal of Research in Science Teaching, 50(2), 209-237. http://doi.org/10.1002/tea.21076

Evagorou, M., Albe, V., Angelides, P., Couso, D., Chirlesan, G., Evans, R. H., et al. (2014). Preparing preservice science teachers to teach socio-scientific (SSI) argumentation, 69, 39-48.

Evagorou, M., Jimenez-Aleixandre, M. P., \& Osborne, J. (2012). "Should We Kill the Grey Squirrels?” A Study Exploring Students' Justifications and Decision-Making. International Journal of Science Education, 34(3), 401-428. http://doi.org/10.1080/09500693.2011.619211

Forbes, C. T., \& Davis, E. A. (2007). Exploring preservice elementary teachers' critique and adaptation of science curriculum materials in respect to socioscientific issues. Science \& Education, 17(8-9), 829854. http://doi.org/10.1007/s11191-007-9080-Z

Friedrichsen, P., Sadler, T. D., Sadler, Graham, K., \& Brown, P. (2016). Design of a socio-scientific issue curriculum unit: Antibiotic resistance, natural selection, and modeling. International Journal of Designs for Learning, 7(1), 1-18.

Jimenez-Aleixandre, M. P. (2002). Knowledge producers or knowledge consumers? Argumentation and decision making about environmental management. International Journal of Science Education, 24(11), 1171-1190. http://doi.org/10.1080/09500690210134857 
Kolstø, S. D. (2001). Scientific literacy for citizenship: Tools for dealing with the science dimension of controversial socioscientific issues. Science Education, 85(3), 291-310.

Lee, Y. C., \& Grace, M. (2012). Students' reasoning and decision making about a socioscientific issue: A crosscontext comparison. Science Education, 96(5), 787-807. http://doi.org/10.1002/sce.21021

Levinson, R. (2006). Towards a Theoretical Framework for Teaching Controversial Socio-scientific Issues. International Journal of Science Education, 28(10), 1201-1224. http://doi.org/10.1080/09500690600560753

Merriam, S. B. (1988). Case study research in education: A qualitative approach.

Owen, R., Macnaghten, P., \& Stilgoe, J. (2012). Responsible research and innovation: From science in society to science for society, with society. Science and Public Policy, 39(6), 751-760. http://doi.org/10.1093/scipol/scs093

Park, S., Jang, J.-Y., Chen, Y.-C., \& Jung, J. (2010). Is Pedagogical Content Knowledge (PCK) Necessary for Reformed Science Teaching?: Evidence from an Empirical Study. Research in Science Education, 41(2), 245-260. http://doi.org/10.1007/s11165-009-9163-8

Ratcliffe, M. (1997). Pupil decision-making about socio-scientific issues within the science curriculum. International Journal of Science Education, 19(2), 167-182. http://doi.org/10.1080/0950069970190203

Sadler, T. D. (2011). Socio-scientific Issues-Based Education: What We Know About Science Education in the Context of SSI. In Socio-scientific Issues in the Classroom (Vol. 39, pp. 355-369). Dordrecht: Springer Netherlands. http://doi.org/10.1007/978-94-007-1159-4_20

Sadler, T. D., \& Fowler, S. R. (2006). A threshold model of content knowledge transfer for socioscientific argumentation. Science Education, 90(6), 986-1004. http://doi.org/10.1002/sce.20165

Sadler, T. D., \& Zeidler, D. L. (2004). Patterns of informal reasoning in the context of socioscientific decision making. Journal of Research in Science Teaching, 42(1), 112-138. http://doi.org/10.1002/tea.20042

Sadler, T. D., Amirshokoohi, A., Kazempour, M., \& Allspaw, K. M. (2006). Socioscience and ethics in science classrooms: Teacher perspectives and strategies. Journal of Research in Science Teaching, 43(4), 353376. http://doi.org/10.1002/tea.20142

Simonneaux, L., \& Simonneaux, J. (2008a). Socio-scientific reasoning influenced by identities. Cultural Studies of Science Education, 4(3), 705-711. http://doi.org/10.1007/s11422-008-9145-6

Simonneaux, L., \& Simonneaux, J. (2008b). Students' socio-scientific reasoning on controversies from the viewpoint of education for sustainable development. Cultural Studies of Science Education, 4(3), 657687. http://doi.org/10.1007/s11422-008-9141-X

Stuckey, M., Hofstein, A., Mamlok-Naaman, R., \& Eilks, I. (2013). The meaning of "relevance" in science education and its implications for the science curriculum. Studies in Science Education, 49(1), 1-34. http://doi.org/10.1080/03057267.2013.802463

Topcu, M. S., Sadler, T. D., \& Yilmaz Tuzun, O. (2010). Preservice Science Teachers' Informal Reasoning about Socioscientific Issues: The influence of issue context. International Journal of Science Education, 32(18), 2475-2495. http://doi.org/10.1080/09500690903524779

Zeidler, D. L. (2015). Socioscientific Issues as a Curriculum Emphasis. In N. G. Lederman \& S. K. Abell (Eds.), Handbook of Research on Science Education (pp. 697-726).

Zeidler, D. L., Sadler, T. D., Simmons, M. L., \& Howes, E. V. (2005). Beyond STS: A research-based framework for socioscientific issues education. Science Education, 89(3), 357-377. http://doi.org/10.1002/sce.20048

Zeidler, D. L., Walker, K. A., Ackett, W. A., \& Simmons, M. L. (2002). Tangled up in views: Beliefs in the nature of science and responses to socioscientific dilemmas. Science Education, 86(3), 343-367. http://doi.org/10.1002/sce.10025

Zohar, A., \& Nemet, F. (2001). Fostering students' knowledge and argumentation skills through dilemmas in human genetics. Journal of Research in Science Teaching, 39(1), 35-62. http://doi.org/10.1002/tea.10008

\section{Author Information}

\begin{tabular}{ll}
\hline Evagorou Maria & Blanca Puig Mauriz \\
University of Nicosia, Cyprus & University of Santiago de Compostela, Spain \\
Contact e-mail: evagorou.m@ unic.ac.cy &
\end{tabular}

